\title{
Foraminiferal Distribution and Sediment Characteristics of Palar Estuary Tamil Nadu, India
}

\author{
Rabina $C^{1}$, Senthil Nathan $D^{2}$, Faizal Khan $A^{3}$ \\ ${ }^{1,2,3}$ Department of Earth Sciences, Pondicherry University, Puducherry, India
}

\begin{abstract}
Foraminiferal assemblage in the Palar estuary comprises more than $85 \%$ of calcareous perforated benthic fauna with higher abundance of rotalids followed by miliolids and agglutinated forms. The study area exhibits alkaline environment and the fauna is abundant in fine to very fine sand. Textural analysis reveals that the sediments are chiefly composed of sand with less mud in the study area, and are deposited mostly in fluvial condition with less marine impact.
\end{abstract}

Keywords: Estuary, benthic foraminifera, sediment, east coast, India.

\section{Introduction}

Foraminifers are one of the most miscellaneous group of shelled micro-organisms in modern oceans, and they are recognized for their remarkable fossil record than for their diversity and richness [31]. They are found from intertidal to the deepest ocean trenches and from the poles to tropics. Many forms are abundant in the deep ocean, some forms survive only in brackish estuaries or salt marshes and they are more peculiar to certain temperature and depth ranges [17], [22], [30]. Estuaries are transition zone between riverine and oceanic environments and is influenced by tides, waves, and the influx of saline water by oceans and flows of fresh water and sediment by rivers.

Estuarine foraminiferal investigations in the Indian estuaries have received meager attention. Initially taxonomic and ecological studies of foraminifera on beaches and estuaries of eastern coast of India have been carried out [3], [4]. Foraminiferal ecology and size distribution of Pennar estuary [25-28], foraminifera from Suddagedda estuary [30] and seasonal variation of foraminifera in Vellar estuary, east coast of India were also documented [24]. Textural analysis is one of the most important basic parameter to determine the mechanism of transport and deposition of sediments; grain size statistical parameters such as mean and standard deviation replicate the energy condition of the depositional environment [11], [12], [2], [16]. Global scenario shows pioneer study on significance of grain size parameters and frequency of size distribution have been done [38], [18], [11]. In Indian coast investigation on texture and composition of Hooghly estuary and near shore environment [33], mechanism of sediment transport in Vellar estuary [20], textural analysis of Coleroon Estuary and Gosthani River Estuary [1], [14] are documented. The present study is aimed to report foraminifera and sediment characteristics of the study area.

\section{Study Area}

The river Palar originates from Nandi Hills in Karnataka and flows ESE from the Western Ghats through Karnataka, Andhra Pradesh and Tamil Nadu. Buckingham canal which runs parallel to the seashore and the Cheyyar River which flows towards east in the Kancheepuram district join with
Palar estuary and finally confluence to the Bay of Bengal near Pudupattinam colony. Depending on the water flow, the development of the mouth bar varies from $30 \mathrm{~m}$ to $500 \mathrm{~m}$ in width. The maximum width of the river is around $1.2 \mathrm{~km}$ and maximum depth of the estuary is $1.5 \mathrm{~m}$ with an average of $0.5 \mathrm{~m}$ and the ephemeral river will connect to the open sea only during NE monsoon [36]. Geological settings of the catchment area include various types of pink and grey gneisses forming part of the Peninsular Gneissic Complex extends southward from the states of Karnataka and Andhra Pradesh and occurs north of Palar River along the northern border of Tamil Nadu and also recent studies indicate that the alkaline plutonic activity extends further NNE, beyond River Palar [35].

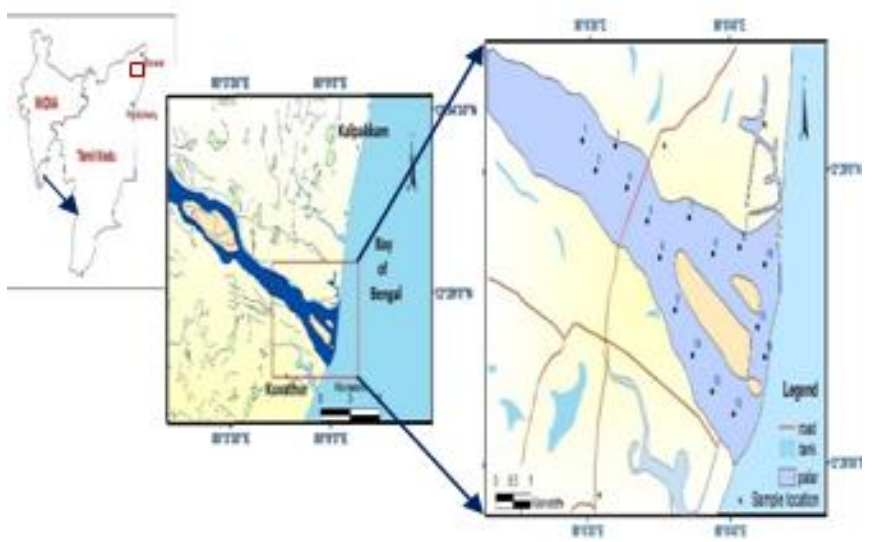

Figure 1: Study area map of Palar estuary

\section{Methodology}

Both surface sediment and water samples were collected from upstream to mouth of the estuary. A total of 16 sediment samples were retrieved from the study area using corer (PVC pipe) with the diameter of $5 \mathrm{~cm}$. Then $50 \mathrm{~g}$ of sample worn out from the top and soaked in Rose Bengal stain solution to differentiate living foraminifera from dead forms, and the rest were transformed into a polythene bag. Bottom water samples were collected from the same location and the temperature, salinity and $\mathrm{pH}$ were measured in situ. 


\section{International Journal of Science and Research (IJSR) \\ ISSN (Online): 2319-7064}

Index Copernicus Value (2013): 6.14 | Impact Factor (2014): 5.611

\subsection{Sample processing for foraminiferal study}

The stained samples were washed over $63 \mu$ sieve to remove saline water, fixatives and the fine silt and clay size sediment particles. Foraminifers were picked from $1 \mathrm{~g}$ of sample and mounted on microfaunal slides.

\subsection{Sample processing for granulometric analysis}

The samples were first air dried then oven dried at $40{ }^{\circ} \mathrm{C}$ overnight in a hot air oven [34], then $100 \mathrm{~g}$ of homogenized sample was taken by cone and quartering method which was further subjected to sieve analysis using ASTM sieves of $1 / 2$ phi interval $(2 \mathrm{~mm}, 1 \mathrm{~mm}, 0.5 \mathrm{~mm}, 0.25 \mathrm{~mm}, 0.125 \mathrm{~mm}$ and $0.063 \mathrm{~mm}$ ) for 15 minutes [39]. The weight of each size fraction was recorded, and the frequency curves as well as cumulative frequency curve were plotted to calculate grain size statistical parameters [11]

\section{Results and Discussion}

Foraminiferal assemblage in the Palar estuary composed of mainly benthic forms with a few Globigerina bulloides, an open ocean plankton. A total of 37 species belonging to 13 genera and nine families identified from the study area. The most abundant forms in the study area were Ammonia beccarii, Ammonia tepida, Ammonia parkinsonia, Elphidium advenum and Nonion grateloupi (abundance $>5 \%$ ) and these four forms except Ammonia beccarii showed increasing trend towards mouth (Figure 2). Ammonia beccarii is a cosmopolitan species which thrive in hyposaline to hypersaline environments since it has been reported from very low salinity lakes to higher marine environments [21]. Relatively low species diversity is noticed in the estuary except the four genera Ammonia, Elphidium, Triloculina and Spriroloculina.

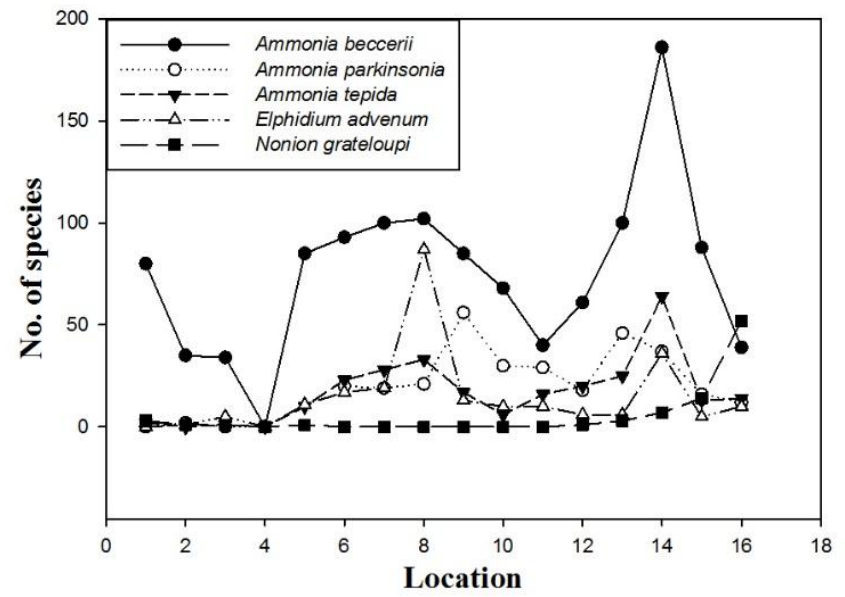

Figure 2: Distribution of abundant species in the estuary

\subsection{Faunal distribution}

The foraminiferal distribution in the Palar estuary was calculated as relative abundance in one gram sample with $>63 \mu$ size fraction. The faunal assemblage in the estuary was dominated by calcareous perforated benthic fauna, while calcareous imperforate porcelaneous and agglutinated forms were very less (Figure 3 ).

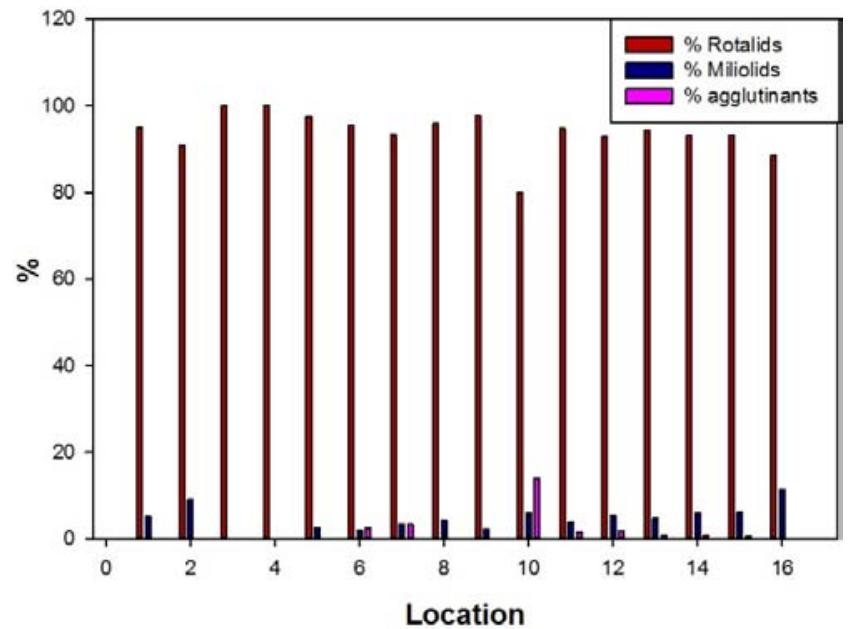

Figure 3: Percentage distribution of foraminifera.

The negligible number of agglutinated forms in the estuary was due to the warm water environment where calcareous forms dominate and the agglutinated forms were under developed since each species has certain tolerance limits as well as temperature optimum [17].

Faunal diversity was high for the samples collected from the river mouth, where more than $75 \%$ of total species in the estuary was obtained. Mixohaline calcareous assemblage such as species of ammonia and elphidium dominates towards mouth of the estuary. Presence of Bolivana lobata, Nonion grateloupi, Amphistegina radiata and broken coarsely perforated calcareous forms directly indicates the marine impact on the estuary. Globigerina bulloides, an open ocean plankton, echinoid spines and ostracoda were also acquired from the study area. These allochthonous forms might have been transported from Bay of Bengal to the estuary.

There is no much significant variation in temperature from upstream to mouth of the estuary and it ranging from $30.7^{\circ} \mathrm{C}$ to $33.1^{\circ} \mathrm{C}$. The hydrogen ion concentration of water from the estuary elucidates the alkaline environment prevailing throughout the area. The values ranges from 7.24 to 8.08 and the salinity of the estuary varies between $12.8 \%$ and $26.2 \%$. In the study area, more diverse forms were found near mouth where salinity was high.

Table 1: List of species

\begin{tabular}{|c|c|}
\hline 1 & Ammobaculites agglutinans \\
\hline 2 & Ammobaculites exiguus \\
\hline 3 & Ammonia beccarii \\
\hline 4 & Ammonia parkinsonia \\
\hline 5 & Ammonia tepida \\
\hline 6 & Amphistegina radiata \\
\hline 7 & Bolivina lobata \\
\hline 8 & Brizalina catanensis \\
\hline 9 & Brizalina spathulata \\
\hline 10 & Brizalina striatula \\
\hline 11 & Cibicides wuellerstorfi \\
\hline 12 & Elphidium advenum \\
\hline 13 & Elphidium charlottense \\
\hline 14 & Elphidium crispum \\
\hline
\end{tabular}




\section{International Journal of Science and Research (IJSR) \\ ISSN (Online): 2319-7064}

Index Copernicus Value (2013): 6.14 | Impact Factor (2014): 5.611

\begin{tabular}{|l|c|}
\hline 15 & Elphidium discodale \\
\hline 16 & Elphidium excavatum \\
\hline 17 & Elphidium somaense \\
\hline 18 & Eponides concameratus \\
\hline 19 & Eponides repandus \\
\hline 20 & Globigerina bulloides \\
\hline 21 & Haynesina depressula \\
\hline 22 & Nonion grateloupi \\
\hline 23 & Nonion scaphum \\
\hline 24 & Pararotalia calcar \\
\hline 25 & Pararotalia inermis \\
\hline 26 & Quinqueloculina agglutinata \\
\hline 27 & Quinqueloculina recta \\
\hline 28 & Quinqueloculina seminulum \\
\hline 29 & Rotalidium annectens \\
\hline 30 & Rotalinoids compressiculus \\
\hline 31 & Spiroloculina antillarum \\
\hline 32 & Spiroloculina excavata \\
\hline 33 & Spiroloculina indica \\
\hline 34 & Textularia agglutinans \\
\hline 35 & Triloculina circularis \\
\hline 36 & Triloculina rotunda \\
\hline 37 & Triloculina trigonula \\
\hline
\end{tabular}

sand and the average mean size is $0.858(\Phi)$. More than $87 \%$ (sample PA 1 - PA 14) of the sediments lies between $0(\Phi)$ to $1(\Phi)$ coarse sand which is deposited in moderately high energy environment. The standard deviation of sediments ranges from $0.3914(\Phi)$ to $1.218(\Phi)$ with an average of $0.7439(\Phi)$. In the study area $94.7 \%$ sediments were moderately sorted to moderately well sorted. Standard deviation of beach sands normally lies within in the range of very well sorted to moderately sorted whereas river sands are moderately well sorted, moderately sorted and poorly sorted [13]. The skewness values ranges from $-0.045(\Phi)$ to $1(\Phi)$ with an average of $0.4356(\Phi)$. Bivariant plot (Figure 3) between skewness and standard deviation shows that the sediments deposited in the riverine environment. The study area is a bar built estuary which restricts the incorporation of marine

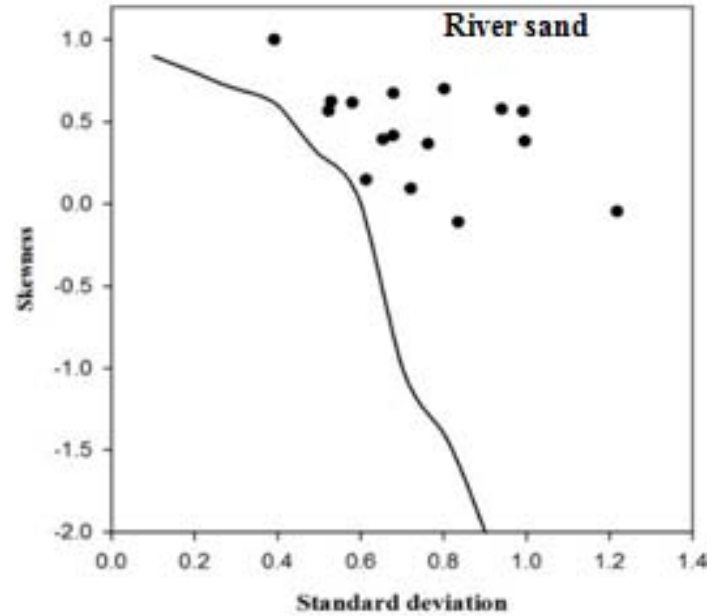

Figure 3: Bivariant plot of standard deviation and skewness

In the Palar estuary the mean size of surface sediments varies from $0.263(\Phi)$ to $2.846(\Phi)$ corresponding to coarse and fine
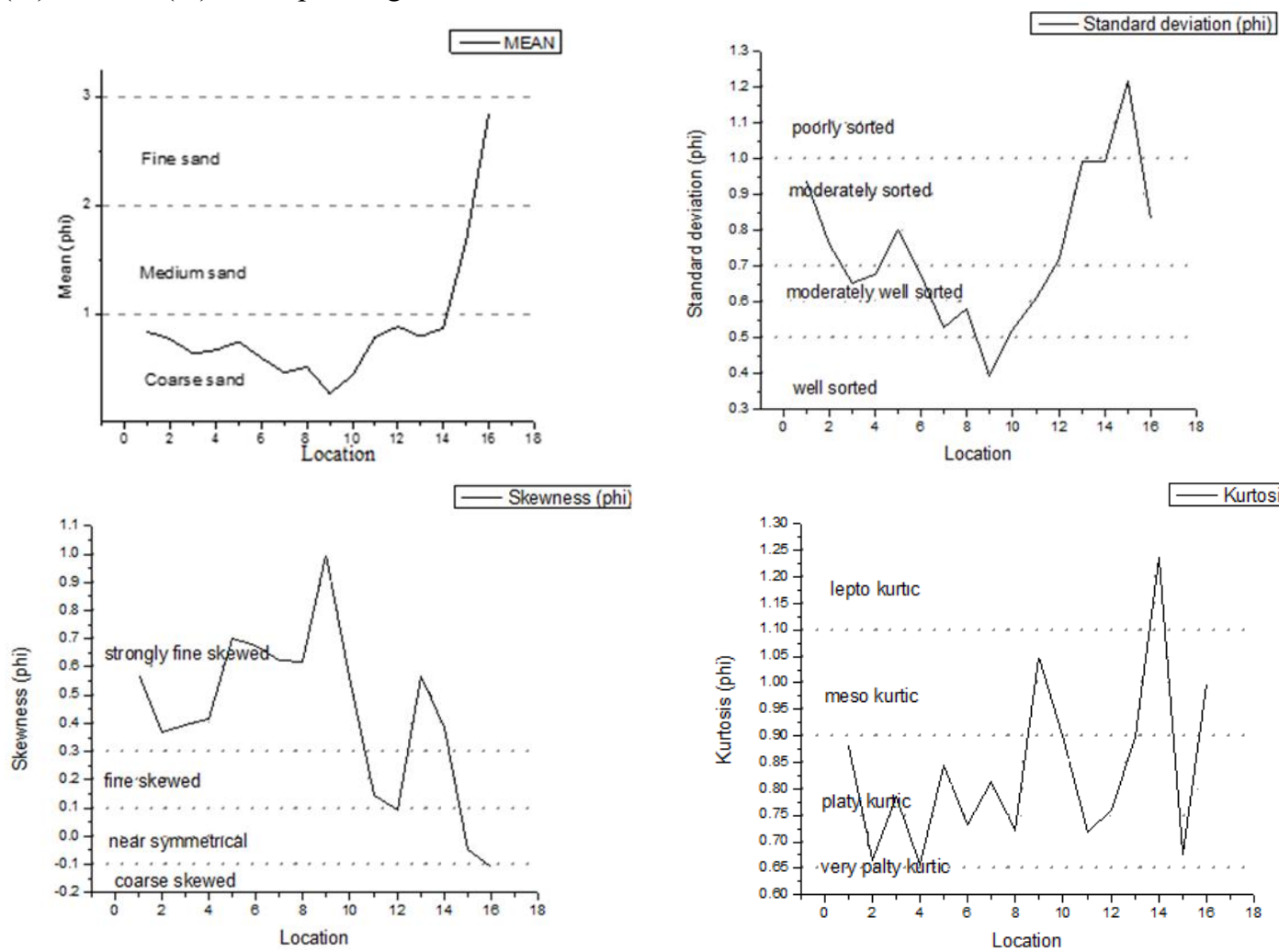

Figure 4: Variogram represents statistical parameters of sediment in the Palar estuary.

Volume 5 Issue 2, February 2016

www.ijsr.net 


\section{International Journal of Science and Research (IJSR) \\ ISSN (Online): 2319-7064}

Index Copernicus Value (2013): 6.14 | Impact Factor (2014): 5.611

sediments. Symmetry of the sample varies from coarse skewed to strongly fine skewed; $87 \%$ of samples shows positive skewness which indicates the excessive fluvial input that is unidirectional transport of sediments to the study area [16]. Usually positive skewness of fluvial deposits results from suspension material overlapping the sediments transported on the bottom through traction and salting, due to the reduced turbulence of fluvial current [11]. In the study area the negative skewness found only in the in the river mouth samples. The lower and higher values of kurtosis in the study area is $0.656(\Phi)$ and $1.2367(\Phi)$ respectively with an average of $0.833(\Phi)$, among these $62.5 \%$ were platykurtic, $18.75 \%$ were mesokurtic, $12.5 \%$ were very platykurtic and $6.25 \%$ were leptokurtic in nature of distribution (Figure 4).

\section{Conclusion}

The foraminiferal assemblage in the Palar estuary is composed of 37 species belonging to 13 genera and nine families of benthic forms including one species of planktonic form. The taxa were dominated by species of Rotalina followed by Miliolina and Textularina. Ammonia, Elphidium, Triloculina and Spriroloculina genera shows comparatively more species diversity in the estuary and Ammonia beccarii is the most dominant taxon. Higher diversity of fauna in the estuary was observed in fine to very fine sand towards mouth where salinity is high. The entire study area exhibits alkaline environment. Presence of coarse sand in the estuary indicates the riverine input, and the winnowing action is responsible for the transportation of finer particles towards the mouth, where the energy is dispersed and fines are deposited due to the development and existence of mouth bar.

\section{Acknowledgement}

We would like to acknowledge UGC for funding this research. Thanks are due to Pondicherry University Central Instrumentation Facility for providing SEM and thanks to friends those who helped to carry out the field work.

\section{References}

[1] A. Irudhayanathan., R. Thirunavukkarasuand, V. Senapathi, "Grain Size characteristics of The Coleroon Estuary Sediments, Tamil Nadu, east coast of India”. In carpathian journal of earth and environmental sciences, pp.151-157, 2011

[2] E.J. Anthony, A. Héquette, "The grain-size characterisation of coastal sand from the Somme estuary to Belgium: Sediment sorting processes and mixing in a tide- and storm-dominated setting". Sedimentary Geology, pp. 369 - 382, 2007.

[3] S. N. Bhalla," Recent foraminifera from Vishakhapatnam beach sands and its relation to the known foramgeographical provinces in the Indian Ocean", National institute of Science India, pp.376 392, 1968.

[4] S. N. Bhalla, "Foraminifera from Marina beach sands of Madras and faunal provinces of the Indian Ocean", Contrib. Cushman Foundation for Foraminifera Research, pp. 156 - 163, 1970.
[5] S. N. Bhalla, N. Khare, D. H. Shanmukha, P. J. Henriques, "Foraminiferal studies in nearshore regions of western coast of India and Laccadives Islands: A review", Indian Journal of Marine Science, pp. 272287, 2007.

[6] S. B. Bhatia, S. N. Bhalla, "Recent foraminifera from becch sand at Puri, Orissa", Journal of Paleontological Society of India, pp.78 - 81, 1964.

[7] N .Colala, "Environmental analysis of sedimentological parameters and heavy mineral sediments in the supply of the beaches in the region of Porto (Northen Portugal)" 2013.

[8] J. A. Cushman, "Foraminifera Their Classification and Economic Use", Cushman Laboratory for Foraminiferal Research Special Publication. No. 1, 1928.

[9] S. G. Dalal, "Interrelationship between environmental parameters and foraminiferal species in Mandovi and Zuari estuaries, Mahasagar" - Bulletin National Institute of Oceanography, pp. 91 - 93, 1976

[10] M. G. Erskian, J. H. Lipps, "Distribution of foraminifera in the Russian River estuary, northern California", Micropaleontology, pp.453-469, 1977.

[11] R.L. Folk, M.C. Ward, "Brazos river bars; a study in the significance of grain size parameters", Journal of Sedimentary petrology, pp. 3-27, 1957.

[12] G.M. Friedman, "Distinction between dune, beach and river sands from their textural characteristics", Journal of Sedimentary Petrology pp.514-529, 1961.

[13] G. M. Friedman, "Dynamic Processes And Statistical Parameters Compared for Size Frequency Distribution of Beach and River Sands", Journal of Sedimentary Petrology, pp. 327-354,1967.

[14] B. Genesh, A.G.S.S. Naidu, J.M. Rao, K.T. Karudu, P.Avatharam, "Studies on textural characteristics of sediments from Gosthani River Estuary Bheemunipatnam, A.P., East Coast of India”, Journal of Indian Geophysical Union, pp. 139-151, 2013.

[15] J.R. Haynes, Foraminifera, Wiley, New York, 1981.

[16] G. Kumar, A.L. Ramanathan, K. Rajkumar, "Textural characteristics of the surface sediments of a Tropical mangrove ecosystem Gulf of Kachchh, Gujarat, India", Indian journal of marine sciences, pp.415-422, 2010.

[17] P. K. Kathal, Microfossils and their applications, CBS Publishers, 1998.

[18] W.C.Krumbein, "Application of Logarithmic Moments to Size Frequency Distribution of Sediments," Journal of Sedimentary Petrology, pp. 35-47, 1936.

[19] A. R. Loeblich H. Tappan, Foraminiferal Genera and Their Classification. New York: Van Nostrand Reinhold, Vol. 1 and 2, 1988.

[20] P.M. Mohan, "Sediment transport mechanism in the Vellar Estuary, east coast of India", Indian Journal of Marine Sciences, pp. 27-31. 2000.

[21] J.W. Murray, Ecology and Palecology of Benthic Foraminfera, John Wiley and Sons, U.K, 1991.

[22] R. Nigam, S.K. Chaturvedi, "Foraminiferal study from Kharo Creek, Kachchh (Gujarat), north-west coast of India". Indian Journal of Marine Science pp.133-138, 2000.

[23] F.B. Phledger, "Ecology of Foraminifera, northwest Gulf of Mexico, Part 1, Foraminifera distributions", Geological Society of America Memoir, pp. 88, 1951. 


\section{International Journal of Science and Research (IJSR) \\ ISSN (Online): 2319-7064}

Index Copernicus Value (2013): 6.14 | Impact Factor (2014): 5.611

[24] R. M. Ramanathan, "Seasonal variations in foraminiferal abundance and their relation to the substrate in Vellar estuary, Andhra Pradesh", Journal of Geological Society of India, pp.40 - 49, 1969.

[25] K. R.Reddy, Ecology of recent foraminifera in the Pennar estuary, A P., India, PhD. Thesis, S. V. University of Tirupati, India, 1973.

[26] K.R. Reddy, R.J.Rao, M.G.C.Naidu, "Living and total foraminiferal fauna Pennar estuary, Andhra Pradesh, India", In Proceedings of the IV Indian Colloquium on Micropaleontology and Stratigraphy, pp. 17-20, 1974.

[27] K.R. Reddy, R. J. Rao, "Size distribution of recent foraminifera - Pennar Estuary, Andhra Pradesh", In Proceedings of the VII Indian Colloquium on Micropaleontology and Stratigraphy p.337,1978.

[28] K.R. Reddy, R.J. Rao," Foraminifera - salinity relationship on the Pennar estuary, India", Journal of Foraminiferal Research, pp.115-119,1984.

[29] R.N. Rao, C. Geetha, S. Shanmughavel, "Benthic foraminiferal colonization of a new mangrove ecosystem - a case study from Pazhaiyakayal, Tuticorin, South-East Coast of India", Journal of the Palaeontological Society of India, pp.119-127, 2012.

[30] T. V. Rao, M. S. Rao, "Recent Foraminifera of Suddagedda estuary, east coast of India" Micropaleontology, pp. 398-419, 1974.

[31] B. K. Sen Gupta, Modern foraminifera, Kluwer Academic Publishers The Netherlands, 2002.

[32] I. Seibold, "Benthic from the coast and lagoon of Cochin (south India)", Rev. Espanola de Micropaleontology, pp. 175 - 213, 1975.

[33] S.K Sesamal, B. K. Sahu, R. C. Panigrahy, "Texture and composition of sediments of Hooghly estuary and near shore environment", Indian Journal of Marine Sciences, pp. 201-202, 1986.

[34] T. Symphonia, D. S .Nathan, "Distribution of Benthic Foraminifera off Cuddalore, Bay of Bengal, Southeast Coast of India", International Research journal of Environmental Sciece, pp. 1222-1225, 2014.

[35] P.M. Tejale, Geology and Mineral Resources of The States of India, Part VI - Tamil Nadu and Pondicherry, Geological Survey of India, Miscellaneous publication No. 30. pp. 1-75, 2006.

[36] R. Thangavelu, P. Poovannan, "Bivalve resources of Palar Estuary", Marine Fisheries Information Service, pp.1-6, 2007.

[37] B. Thilagavathi, D. V. Varadharajan, J. Manoharan, S.Vijayalakshmi T. Balasubramanian, "Taxonomy and Distribution of Benthic Foraminifera from the Sediment of Palk Strait, South East Coast of India", International Journal of pharmaceutical \& Biological Archives, pp. 1129-1136, 2012.

[38] J.A. Udden, "Mechanical composition of clastic sediments", Bulletin of the Geological Society of America, pp. 655-744, 1914.

[39] C. K. Wentworth, "A Scale of Grade and Class Terms for Clastic Sediments", The Journal of Geology, pp. 377-392, 1922. 